\title{
Kajian Model Penukaran Kadar Hujan untuk Integrasi Masa 60 Minit kepada 1 Minit di Malaysia
}

\author{
(Study on Rainrate Conversion Models for 60 Minutes to 1 Minute Integration Times in Malaysia) \\ Nor Irza Shakhira Bakhtir* \& Mandeep Singh Jit Singh
}

\begin{abstract}
ABSTRAK
Perkembangan pesat teknologi komunikasi tanpa wayar telah menyebabkan penggunaan jalur frekuensi mencapai tahap tepu terutamanya di negara-negara maju. Ini telah mendorong jurutera sistem telekomunikasi meneroka jalur frekuensi di atas jalur Ku $(10 \mathrm{GHz})$. Namun begitu, titisan hujan amat memberi kesan kepada isyarat yang merambat pada jalur frekuensi di atas $10 \mathrm{GHz}$. Justeru, ramalan pelemahan hujan ke atas perambatan isyarat elektromagnet menggunakan kadar hujan bersela masa 1 minit adalah penting. Di kebanyakan negara, data kadar hujan bersela masa 60 minit lebih mudah diperolehi berbanding data hujan yang bersela masa lebih pendek. Oleh sebab itu, kaedah penukaran taburan hujan dengan sela masa 60 minit diperlukan untuk mendapatkan kadar hujan bersela masa 1 minit. Kajian ini dijalankan dengan menggunakan data hujan dari 10 buah stesen pencerap hujan Jabatan Pengairan dan Saliran di seluruh Malaysia untuk tempoh 3 tahun dari 2011 hingga 2013 bagi menentukan model penukaran kadar hujan untuk sela masa 60 minit yang terbaik di Malaysia. Beberapa model penukaran kadar hujan untuk sela masa 60 minit kepada 1 minit dikaji di antaranya adalah model Segal, model Burgueno et al., model Chebil dan Rahman, model Lee et al., model Lavergnat dan Golé dan model Moupfouma dan Martin. Daripada keputusan yang diperolehi, didapati model Chebil dan Rahman memberikan keputusan terbaik untuk diguna pakai di Malaysia dengan memberikan nilai ralat Root Mean Square (RMS) di bawah 20\% bagi kesemua lokasi. Hasil kajian yang diperolehi daripada projek ini adalah sangat berguna dalam menentukan pelemahan hujan bagi merekabentuk sebuah sistem perhubungan satelit yang mempunyai kebolehsediaan dan kebolehcapaian yang tinggi.
\end{abstract}

Kata kunci: integrasi masa; taburan kadar hujan; kaedah penukaran

ABSTRACT

The rapid development of wireless communication technologies has led the frequency band reach its saturated level, particularly in developed countries. This has drawn the attention of telecommunication systems engineer to explore the frequency band above the $\mathrm{Ku}$ band $(10 \mathrm{GHz})$. However, raindrops significantly affect the signal propagating in the frequency bands above $10 \mathrm{GHz}$. Thus, prediction of rain attenuation on the propagation of electromagnetic signals using 1 minute rainfall rate is important. In many countries, 60 minutes rainfall rate distribution are widely available compared to rainfall rate distribution with shorter integration times. Therefore, conversion method is essential to predict 1 minute rainfall rate distribution from 60 minutes rainfall rate distribution. This study was conducted using rainfall data from 10 stations of Malaysia Drainage and Irrigation Department over 3 years period of 2011 to 2013 to determine the best conversion model for 60 minutes rainfall rate in Malaysia. Several conversion models is presented in this study such as Segal, Burgueno et al., Chebil and Rahman, Lee et al., Lavergnat and Golé and Moupfouma and Martin. From the results, Chebil and Rahman's model is found to be the most suitable model to be used in Malaysia with Root Mean Square (RMS) error below $20 \%$ for all locations. This project is very useful to determine rain attenuation in designing a high availability and accessibility satellite communication system.

Keywords: integration time; rainfall rate distribution; conversion method

\section{PENGENALAN}

Malaysia merupakan negara yang terletak pada berhampiran dengan Garisan Khatulistiwa. Kedudukan geografi merupakan faktor penting yang mempengaruhi ciri-ciri iklim di Malaysia iaitu mempunyai suhu yang seragam dan kelembapan yang tinggi. Malaysia juga mendapat curahan hujan lebat sepanjang tahun dan jumlah hujan tahunan yang diterima adalah di antara $2000 \mathrm{~mm}$ hingga $3000 \mathrm{~mm}$. Selain faktor kedudukan geografi, taburan hujan yang diterima di Malaysia turut dipengaruhi oleh kedudukan Malaysia yang dikelilingi air laut serta dua jenis tiupan angin monsun yang utama iaitu angin Monsun Timur Laut dan angin Monsun Barat Daya.

Hujan adalah salah satu unsur kerpasan berbentuk cecair yang turun ke bumi bagi melengkapkan proses kitaran bumi 
(Hadi 2011). Impak hujan kepada sesuatu sistem bergantung kepada keamatan hujan pada masa tersebut. Faktor-faktor yang mempengaruhi keamatan atau intensiti hujan adalah seperti ketepuan molekul air, kadar sejatan, haba pendam pelakuran, proses pembentukan awan serta kadar liputan awan. Selain daripada itu, terdapat faktor luaran seperti kepelbagaian bentuk muka bumi tempat hujan itu turun, pergerakan angin monsun dan kedudukan garis lintang yang turut menyumbang kepada struktur titisan hujan (Sharifah 2010).

Taburan hujan antara satu kawasan dengan kawasan yang lain adalah berbeza, bergantung sepenuhnya kepada kadar keamatan atau intensiti hujan bagi lokasi tersebut. Aktiviti mencerap data hujan biasanya dilakukan oleh badan atau agensi meteorologi, pusat-pusat pencerapan bumi, pusat pengairan/saliran, ahli-ahli kajibumi dan juga ahli-ahli akademik bagi tujuan pembelajaran dan penyelidikan. Datadata hujan yang dicerap dapat menghasilkan statistik indeks hujan yang dapat digunakan oleh penyelidik-penyelidik untuk membuat kajian dalam pelbagai bidang yang mana salah satunya adalah bidang perhubungan komunikasi satelit.

Corak taburan hujan adalah salah satu aspek penting dalam merekabentuk sistem perhubungan komunikasi satelit yang berkualiti serta mempunyai ketahanan yang tinggi terhadap pelemahan isyarat (Hasniza 2013). Kesan pelemahan isyarat akibat hujan amat ketara terutama bagi isyarat yang berfrekuensi tinggi melebihi $10 \mathrm{GHz}$ yang mana kewujudan hujan boleh menyebabkan pengecilan serta kehilangan isyarat yang maksimum terutamanya untuk perambatan gelombang pendek. Ini akan mengakibatkan mutu dan kualiti isyarat penerimaan terjejas dan mengganggu prestasi isyarat tepat. Secara tidak langsung memberi impak terhadap keupayaan, kebolehsediaan dan kebolehpercayaan sistem komunikasi tersebut untuk menyampaikan maklumat. Oleh yang demikian, bagi merekabentuk sebuah sistem perhubungan satelit yang mempunyai kebolehsediaan dan kebolehcapaian yang tinggi, pereka sistem gelombang mikro harus dapat meramal pelemahan hujan dengan tepat dan jitu.

Menurut ITU-R P.837-6, bagi mengatasi masalah pelemahan hujan untuk sistem perhubungan satelit, anggaran yang tepat mengenai kesan pelemahan hujan ke atas perambatan isyarat elektromagnet menggunakan kadar hujan bersela masa 1 minit adalah penting (ITU-R P.837-6. 2012). Data kadar hujan bersela masa 1 minit digunakan kerana data hujan yang dicerap dengan sela masa yang lebih pendek memberi kesan terhadap perubahan pantas bagi keadaan taburan tokokan kadar hujan yang lebat dalam sela masa. Namun, di kawasan tropika, taburan kadar hujan dengan sela masa 1 minit adalah terhad berbanding dengan taburan hujan dengan sela masa yang lebih besar seperti 5 minit, 10 minit, 30 minit dan 60 minit (Chebil \& Rahman 1999). Ini adalah kerana bagi tolok hujan yang mempunyai keupayaan membaca kadar hujan setiap 1 minit diperlukan dalam kuantiti yang banyak (Mandeep et al. 2007). Statistik hujan jangka panjang untuk taburan kadar hujan kebanyakannya disediakan pada sela masa yang lebih panjang $(5,10,30$, 60 minit) di seluruh dunia dan di kebanyakan negara, data kadar hujan bersela masa 60 minit lebih mudah diperolehi berbanding data hujan yang bersela masa lebih pendek (1, 5 dan 10 minit).

Banyak kajian-kajian lepas telah dijalankan di kawasan tropika untuk mengenalpasti model penukaran kadar hujan yang terbaik untuk sela masa yang lebih panjang kepada kadar hujan sela masa 1 minit. Di antaranya adalah kajian Mandeep dan Hassan yang membandingkan kadar hujan model penukaran dengan data cerapan di kawasan asia tenggara menggunakan model Segal, Burgueno, Chebil dan Rahman, Lee serta Moupfouma dan Martin. Daripada kajian tersebut didapati model Segal memberikan keputusan yang terbaik (Mandeep \& Hassan 2008).

Kajian Chebil dan Rahman yang membangunkan model penukaran kadar hujan berdasarkan model Segal merupakan salah satu kajian yang menggunakan data hujan di Malaysia. Data hujan 1 minit yang digunakan dalam kajian ini dicerap di 3 lokasi iaitu di Universiti Teknologi Malaysia di Kuala Lumpur, Universiti Sains Malaysia (USM) di Seri Iskandar, Perak dan Sekolah Menengah Vokasional (SMV) di Bota, Perak. Dalam kajian ini, ciri taburan hujan di USM dan SMV dianggap sama dengan Ipoh yang merupakan ibu negeri Perak, memandangkan kedua-dua lokasi adalah berhampiran dengan Ipoh. Oleh itu, purata taburan hujan di USM dan SMV digunakan untuk mewakili taburan hujan di Ipoh. Manakala data hujan 60 minit yang digunakan dalam kajian ini dicerap di 35 lokasi di seluruh Malaysia termasuk di Kuala Lumpur dan Ipoh. Untuk membangunkan model penukaran kadar hujan, Chebil dan Rahman telah membuat perbandingan data hujan 1 minit dan 60 minit untuk 2 lokasi iaitu di Kuala Lumpur dan Ipoh.

Salah satu kajian lain yang menggunakan data hujan di Malaysia adalah kajian Chun dan Mandeep. Kajian ini membuat perbandingan ke atas model penukaran kadar hujan menggunakan model penukaran seperti model Segal, Burgueno, Chebil dan Rahman, Lee, EXCELL RSC dan Lavergnat dan Golé untuk menukar kadar hujan dari sela masa yang lebih panjang iaitu 5, 10,30 dan 60 minit kepada 1 minit. Hasil dapatan kajian ini mendapati model Segal memberikan nilai ralat RMS yang terendah. Namun begitu, kajian ini tidak merangkumi seluruh kawasan di Malaysia kerana data hujan yang digunakan dalam kajian ini dicerap di Kuching Sarawak (Chun \& Mandeep 2013).

Justeru, untuk mendapatkan model penukaran yang sesuai digunakan di seluruh Malaysia, kajian ini dijalankan menggunakan data hujan di sepuluh (10) buah lokasi stesen di seluruh Malaysia seperti dalam Jadual 1 dan Rajah 1. Kajian ini akan menumpukan kepada kaedah penukaran taburan hujan dengan sela masa 60 minit kepada sela masa 1 minit untuk dengan menggunakan data hujan sela masa 60 minit dan 1 minit daripada Jabatan Pengairan dan Saliran Malaysia untuk tempoh tiga tahun (2011 hingga 2013) iaitu bermula 1 Januari 2011 hingga 31 Disember 2013 di sepuluh lokasi stesen pencerap hujan. Menurut saranan ITU-R P.837, data meteorologi tempatan yang digunakan untuk menukar sela masa kadar hujan haruslah dalam tempoh tiga (3) tahun dan ke atas bagi memastikan kestabilan statistik (ITU-R P.837-6. 
JADUAL 1. Parameter lokasi kajian Stesen Pencerapan Hujan

\begin{tabular}{|c|c|c|c|}
\hline \multirow{2}{*}{$\begin{array}{c}\text { Kod } \\
\text { Stesen }\end{array}$} & \multirow[t]{2}{*}{ Nama Stesen } & \multicolumn{2}{|c|}{ Lokasi } \\
\hline & & Latitud & Longitud \\
\hline \multirow[t]{2}{*}{6603002} & PERLIS (Stesen Padang Besar di Titi Keretapi) & & \\
\hline & & $06^{\circ} 39^{\prime} 25^{\prime \prime}$ & $100^{\circ} 18^{\prime} 35^{\prime \prime}$ \\
\hline \multirow[t]{2}{*}{5303053} & PRAI, PENANG (Stesen Kompleks Prai) & & \\
\hline & & $05^{\circ} 22^{\prime} 55^{\prime \prime}$ & $100^{\circ} 23 ’ 30^{\prime \prime}$ \\
\hline \multirow[t]{2}{*}{4511111} & PERAK (Stesen Politeknik Ungku Omar) & & \\
\hline & & $04^{\circ} 35^{\prime} 20^{\prime \prime}$ & $101^{\circ} 07^{\prime} 30^{\prime \prime}$ \\
\hline \multirow[t]{2}{*}{3116003} & KUALA LUMPUR (Stesen JPS Wilayah Persekutuan) & & \\
\hline & & $03^{\circ} 09^{\prime} 05^{\prime \prime}$ & $101^{\circ} 41^{\prime} 05^{\prime \prime}$ \\
\hline \multirow[t]{2}{*}{3717101} & SELANGOR (Stesen Bukit Fraser) & & \\
\hline & & $03^{\circ} 42^{\prime} 43^{\prime \prime}$ & $101^{\circ} 44^{\prime} 18^{\prime \prime}$ \\
\hline \multirow[t]{2}{*}{3833002} & PAHANG (Stesen JPS Negeri Pahang, Kuantan) & & \\
\hline & & $03^{\circ} 48^{\prime} 30^{\prime \prime}$ & $103^{\circ} 19^{\prime} 45^{\prime \prime}$ \\
\hline \multirow[t]{2}{*}{5331048} & TERENGGANU (Setor JPS Kuala Terengganu) & & \\
\hline & & $05^{\circ} 19^{\prime} 05^{\prime \prime}$ & $103^{\circ} 08^{\prime} 00^{\prime \prime}$ \\
\hline \multirow[t]{2}{*}{6122064} & KELANTAN (Setor JPS Kota Bharu) & & \\
\hline & & $06^{\circ} 06^{\prime} 30^{\prime \prime}$ & $102^{\circ} 15^{\prime} 25^{\prime \prime}$ \\
\hline \multirow[t]{2}{*}{1403001} & SARAWAK (Stesen Kuching Airport) & & \\
\hline & & $01^{\circ} 28^{\prime} 55^{\prime \prime}$ & $110^{\circ} 20^{\prime} 15^{\prime \prime}$ \\
\hline \multirow[t]{2}{*}{5961001} & SABAH (Stesen Kiansam) & & \\
\hline & & $05^{\circ} 59^{\prime} 05^{\prime \prime}$ & $116^{\circ} 10^{\prime} 40^{\prime \prime}$ \\
\hline
\end{tabular}

Sumber: JPS

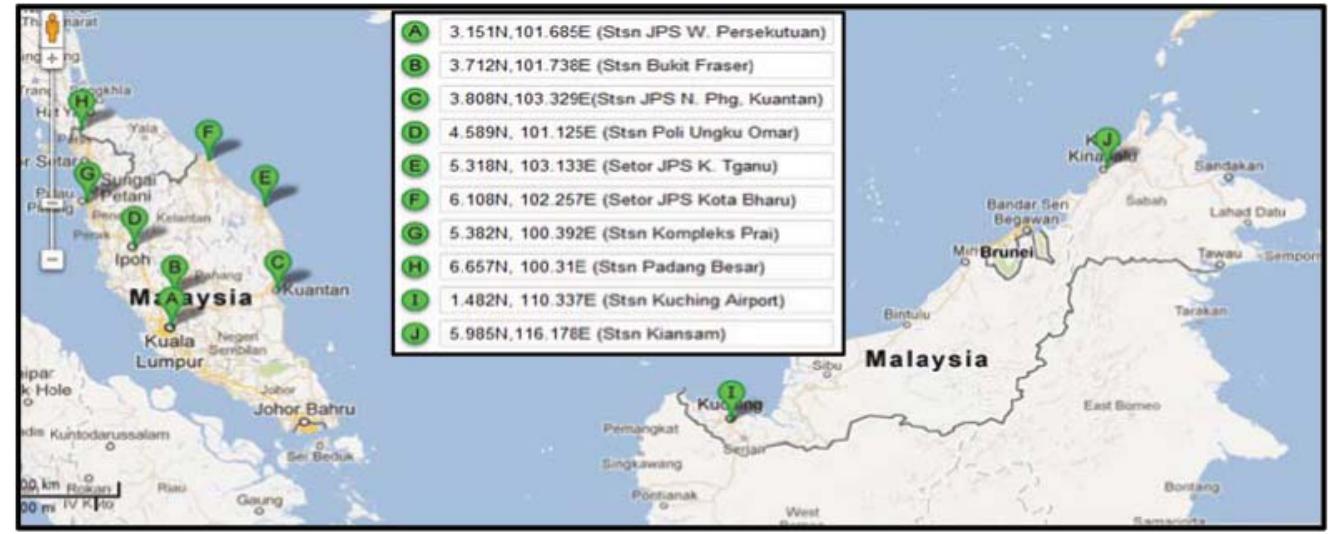

RAJAH 1. Peta lokasi 10 buah stesen pencerap hujan JPS yang dipilih Sumber: Google Map 2014

2012). Model-model penukaran kadar hujan yang dipilih dalam kajian ini adalah berdasarkan kesesuaian model-model tersebut dari kajian-kajian lepas dan antara model-model yang dikaji adalah Segal, Burgueno, Chebil dan Rahman, Lee, Lavergnat dan Golé serta Moupfouma dan Martin.

\section{MODEL PENUKARAN KADAR HUJAN}

Bahagian ini meliputi pengenalan tentang model-model penukaran kadar hujan yang digunakan dalam kajian ini serta kaedah pengiraan menggunakan kaedah model-model penukaran hujan ini.
MODEL SEGAL

Model ini dibangunkan untuk mengkaji hubungan di antara taburan kumulatif kadar hujan untuk sela masa yang berbeza di beberapa lokasi di Kanada dan untuk mendapatkan ciri empirikal untuk memenuhi keperluan pereka sistem gelombang mikro pada masa itu. Model Segal dibangunkan berdasarkan rekod data hujan yang diperolehi daripada carta timba tolok hujan harian selama sepuluh (10) tahun di setiap 45 lokasi di Kanada. 45 stesen terletak merentasi kawasan melebihi $5000 \mathrm{~km}$, termasuk tujuh (7) sampel dari 14 zon iklim hujan yang telah ditentukan oleh Consultative Committee on International Radio (CCIR) (1982a) untuk tujuan perambatan radio (Segal 1986). Model yang dibangunkan oleh Segal 
telah diterima dan diguna pakai oleh ITU (2003a, b, 2006). Persamaan penukaran kadar hujan adalah seperti berikut:

$$
R_{1}(P)=\rho_{\tau}(P) R_{\tau}(P)
$$

dengan

$$
\rho_{\tau}(P)=a P^{b},
$$

di mana $\rho_{\tau}(P)$ adalah faktor penukaran, $R_{1}(P)$ adalah kadar hujan melebihi pada kebarangkalian berlakunya $P$ untuk integrasi masa 1 minit, $R_{\tau}(P)$ adalah kadar hujan sepadan pada $\tau$ minit integrasi masa, manakala $a$ dan $b$ adalah pekali regresi yang diperolehi daripada data cerapan. Dalam kajian ini, nilai parameter $a$ dan $b$ menggunakan nilai dalam kajian penukaran taburan kadar hujan di Malaysia yang telah dijalankan oleh Chun dan Mandeep, di mana nilai yang digunakan adalah 1.539 dan -0.0635 (Chun \& Mandeep 2013).

\section{MODEL BURGUENO}

Model Burgueno et al. dibangunkan menggunakan simpanan data kadar hujan selama 49 tahun yang direkodkan di Barcelona (CCIR - zon L), menggunakan tolok hujan Jardi. Tolok hujan Jardi merekodkan carta kadar hujan secara berterusan pada tindak balas 10s dan ini bermakna kadar hujan yang direkodkan adalah kuasi-merta. Namun begitu, ramalan pelemahan akibat hujan untuk pautan komunikasi tidak menggunakan kadar hujan kuasi-merta kerana perubahan kadar hujan yang pantas tidak dapat diterjemahkan kepada perubahan pelemahan yang sebetulnya. Burgueno et al. telah membangunkan persamaan yang berkadar terus yang dapat diaplikasikan di seluruh dunia untuk hubungan kadar hujan 1 minit dan $\tau$ minit integrasi masa berdasarkan kejadian hujan jangka masa panjang di Barcelona, Sepanyol. Persamaan model Burgueno mengaplikasikan prinsip padanan hukum kuasa (Burgueno et al. 1988).

$$
R_{1}(P)=a R_{\tau}^{b}(P)
$$

$R_{1}(P)$ dan $R_{\tau}(P)$ adalah kadar hujan dengan sela persampelan 1 minit dan $\tau$ minit pada peratusan masa $P$, manakala $a$ dan $b$ mewakili pembolehubah penukaran. Dalam kajian ini, nilai parameter $a$ dan $b$ menggunakan nilai 6.4372 dan 0.6170 (Chun \& Mandeep 2013).

\section{MODEL CHEBIL DAN RAHMAN}

Model Chebil dan Rahman dibangunkan berdasarkan pengubahsuaian ke atas faktor penukaran model Segal dengan memperkenalkan pembolehubah tambahan prinsip eksponen. Parameter ini memberi fleksibiliti dalam model ini dengan membenarkan nilai mutlak yang sesuai dan mencukupi untuk nilai kiraan bagi komponen penukaran. Model Chebil dan Rahman menggunakan data hujan 60 minit dicerap untuk Jabatan Meteorologi Malaysia di 35 lokasi di Malaysia dari tahun 1991 hingga 1998. Tolok hujan yang digunakan untuk mencerap hujan adalah tolok hujan jenis Casella dengan ketepatan $0.5 \mathrm{~mm}$. Sisihan harian bagi gangguan perolakan kejadian hujan diambil kira dan dipertimbangkan dalam pendekatan ini, namun stratiform kejadian hujan yang mengakibatkan hujan lebat diabaikan (Chebil \& Rahman 1999). Penukaran taburan hujan 60 minit kepada 1 minit diberikan dalam persamaan berikut:

$$
\rho_{60}(P)=R_{1}(P) / R_{60}(P)
$$

di mana $\rho_{60}(P)$ diberikan dalam Hukum Kuasa Eksponensial.

$$
\rho_{60}(P)=a P^{b}+c e^{(d P)}
$$

di mana peratusan masa diberikan sebagai $P$, kadar hujan untuk integrasi masa 1 minit dan 60 minit terhadap peratusan masa diberikan sebagai $R_{1}(P)$ dan $R_{60}(P)$ manakala pembolehubah regresi diberikan sebagai $a, b, c$ dan $d$. Dalam kajian ini, nilai parameter $a, b, c$ dan $d$ menggunakan nilai $0.7226,1.2110$, 2.0880 dan -1.0440 (Chun \& Mandeep 2013).

MODEL LAVERGNAT DAN GOLÉ

Model Lavergnat dan Golé dibangunkan berdasarkan data yang dicerap menggunakan disdrometer yang menganalisis masa ketibaan dan struktur titisan hujan. Data hujan dicerap selama 25 bulan (Mei 1992 hingga Mei 1994) di Paris, Perancis. Pendekatan kajian Lavergnat dan Golé tidak mempertimbangkan intensiti hujan dan parameter hujan yang lain seperti gangguan perolakan dan startiform kejadian hujan (Lavergnat \& Gole 1998). Model Lavergnat dan Golé memperkenalkan faktor penukaran $h$ untuk menskala kadar hujan, $R_{T}$ dan kebarangkalian, $P_{T}$ seperti berikut:

$$
\begin{gathered}
R_{1}=R_{T} / h^{\alpha} \\
P\left(R_{1}\right)_{1}=h^{\alpha} P\left(R_{T}\right)_{T}
\end{gathered}
$$

di mana $h=1 / T$ dan $\alpha=0.1609$. $\alpha$ adalah pekali yang telah ditentukan secara empirik.

MODEL LEE

Model Lee et al. dibangunkan berdasarkan cerapan kadar hujan di Korea dan menghasilkan taburan kumulatif kadar hujan untuk integrasi masa yang berbeza iaitu 1, 10, 20, 30 dan 60 minit. Data kadar hujan dengan integrasi masa yang berbeza ini dicerap menggunakan tolok hujan optikal (Lee et al. 2000). Lee et al. mencadangkan untuk menggunakan taburan keseluruhan kejadian hujan untuk meramal data kadar hujan. Penukaran masa kebarangkalian kadar hujan dari $\tau$ minit kepada 1 minit adalah seperti berikut:

$$
P_{1}=a P_{\tau} 10^{\left[b \exp \left(-\frac{t}{24.28}\right)\right]}
$$

di mana kebarangkalian untuk nilai tertentu bagi hujan pada 1 minit dan $\tau$ minit berlaku diberikan oleh $P_{1}$ dan $P_{\tau}, \tau$ mewakili selang persampelan untuk tolok hujan, manakala $a$ dan $b$ adalah pekali regresi. Dalam kajian ini, nilai parameter $a$ dan 
$b$ menggunakan nilai 10.26 dan -8.504 (Chun \& Mandeep 2013).

\section{MODEL MOUPFOUMA DAN MARTIN}

Model Moupfouma dan Martin dibangunkan untuk lingkungan integrasi masa di antara 1 hingga 60 minit menggunakan data kadar hujan yang dicerap oleh Makmal Rutheford Appleton di Chilbolton, United Kingdom. Data kadar hujan dicerap dari tahun 1985 hingga 1992 menggunakan peralatan menggunakan tolok hujan baldi menjongket. Model ini menggunakan kaedah padanan hukum kuasa untuk meramal taburan kumulatif kadar hujan untuk kawasan yang bersuhu sederhana dan tropika (Moupfouma \& Martin 1995). Kadar hujan yang melebihi peratusan masa $0.01 \%$ untuk integrasi masa 1 minit diberikan sebagai

$$
R(1 \mathrm{~min})_{0.01}=\left[R(\tau \min )_{0.01}\right]^{\alpha},
$$

dengan

$$
\alpha=0.987[\tau(\mathrm{min})]^{0.061},
$$

di mana $R(\tau \min )_{0.01}$ adalah kadar hujan yang melebihi peratusan masa $0.01 \%$ untuk $\tau$ min masa integrasi, dan $\tau$ (min) adalah masa integrasi $\tau$ min.

Dengan menggunakan persamaan (9), Moupfouma dan Martin mendapatkan model ramalan taburan kumulatif kadar hujan berdasarkan persamaan di bawah

$$
\begin{aligned}
P(R \geq r)= & 100\left\{\frac{\left[R(\tau \min )_{0.01}+1\right]}{r+1}\right\}^{b} \\
& x \exp \left\{u\left[R(1 \mathrm{~min})_{0.01}-r\right]-\ln \left(10^{4}\right)\right\},
\end{aligned}
$$

di mana

$$
\begin{gathered}
b=\left\{\left[r-R(1 \mathrm{~min})_{0.01}\right] / R(1 \mathrm{~min})_{0.01}\right\} x \\
\ln \left[1+r / R(1 \mathrm{~min})_{0.01}\right. \\
u=\ln \left(10^{4}\right) /\left(R(1 \mathrm{~min})_{0.01} \exp \left\{-\lambda\left[r / R(1 \mathrm{~min})_{0.01}\right]^{\gamma}\right\}\right),
\end{gathered}
$$

dan $r$ adalah kadar purata hujan 1 minit ( $\mathrm{mm} / \mathrm{j})$ yang melebihi kebarangkalian kejadian $P$ dalam setahun dengan syarat $r$ $\geq 2 \mathrm{~mm} / \mathrm{j}$, manakala $\lambda$ dan $\gamma$ adalah pekali regresi. Dalam kajian ini, nilai untuk parameter $\lambda$ dan $\gamma$ menggunakan nilai 0.707 dan 0.060 masing-masing yang mana nilai ini adalah nilai yang ditentukan di Malaysia menurut kajian Kamal et al. (Kamal et al. 2008).

\section{KAEDAH KAJIAN}

Bahagian ini meliputi proses kajian yang dijalankan bagi menentukan Model Penukaran Kadar Hujan bagi sela masa 60 minit yang terbaik di Malaysia. Secara umumnya kaedah kajian ini terbahagi kepada tiga bahagian iaitu:
BAHAGIAN I

1. Mengenalpasti dan memilih Model Penukaran Kadar Hujan yang digunakan dalam kajian ini.

2. Memilih 10 lokasi stesen pencerap hujan di seluruh Malaysia.

3. Mendapatkan data hujan dengan sela masa 60 minit dan 1 minit setiap lokasi untuk tempoh 3 tahun (bermula 1 Januari 2011 hingga 31 Disember 2013) dari Bahagian Pengurusan Sumber Air dan Hidrologi, Jabatan Pengairan dan Saliran Malaysia. Data cerapan sela masa 60 minit digunakan dalam model-model penukaran kadar hujan untuk ditukar kepada data hujan 1 minit manakala data cerapan sela masa 1 minit dijadikan rujukan dan pengesahan. Di peringkat ini juga, turut dimuatkan tentang instrumen pengumpulan data oleh JPS.

BAHAGIAN II

1. Proses penapisan dan pemprosesan data cerapan hujan sela masa 60 minit yang diperolehi yang seterusnya digunapakai dalam enam (6) model penukaran kadar hujan yang dipilih.

2. Berikut adalah asas kaedah pengiraan kadar hujan tahunan untuk sela masa 60 minit yang dijalankan:

$$
\begin{aligned}
1 \text { Tahun } & =365 \text { hari } \times 24 \text { jam } \\
& =8760 \text { jam }
\end{aligned}
$$

Kadar hujan setahun

$=\frac{\text { Bilangan sampel per jam }}{527040} \times 100 \%$

1. Proses penapisan dan pemprosesan data cerapan hujan sela masa 1 minit yang diperolehi dijadikan rujukan dan pengesahan.

2. Berikut adalah asas kaedah pengiraan kadar hujan tahunan untuk sela masa 1 minit yang dijalankan:

$$
\begin{aligned}
1 \text { Tahun } & =366 \text { hari } \times 24 \text { jam } \times 60 \text { minit } \\
& =527040 \text { minit }
\end{aligned}
$$

Kadar hujan setahun

$=\frac{\text { Bilangan sampel per jam }}{527040} \times 100 \%$

\section{BAHAGIAN III}

1. Melaksanakan enam kaedah penukaran kadar hujan ke atas data-data yang ditapis dan diproses dan membuat perbandingan antara Model Penukaran Kadar Hujan dan data cerapan.

2. Keputusan hasil pengiraan penukaran kadar hujan dipersembahkan dalam bentuk jadual dan graf bagi memudahkan proses perbandingan dan analisa dibuat.

3. Pengiraan bagi mendapatkan Model Penukaran Kadar Hujan terbaik berdasarkan data cerapan di 10 buah lokasi stesen yang dipilih. Model penukaran terbaik ini ditentukan oleh nilai RMS ralat relatif yang paling minimum. Ini dapat disahkan melalui analisa graf dengan 
melihat nilai ramalan model yang paling hampir dengan nilai cerapan.

4. Peratusan ralat relatif, $E_{r e l}(\%)$ di antara nilai data model penukaran, $R_{\text {predicted }}$ dengan nilai data cerapan, $R_{\text {measured }}$ diberikan oleh persamaan berikut:

$$
E_{\text {rel }}=\frac{R_{\text {predicted }}-R_{\text {measured }}}{R_{\text {measured }}} \times 100 \%
$$

5. Nilai punca-min-kuasa-dua, $D_{e}$ (RMS) boleh dikira menggunakan ralat min, $\mu_{e}$ dan sisihan piawai, $\sigma_{e}$ melalui persamaan:

$$
D_{e}=\sqrt{ }\left(\mu_{e}\right)^{2}+\left(\sigma_{e}\right)^{2}
$$

\section{KEPUTUSAN DAN PERBINCANGAN}

Berikut adalah keputusan hasil pengiraan penukaran kadar hujan yang dipersembahkan dalam bentuk jadual dan graf bagi memudahkan proses perbandingan dan analisa. Graf kadar hujan kumulatif untuk tahun 2011 hingga 2013 melawan peratusan masa tahunan diplot dan dipersembahkan bagi data model penukaran dan data cerapan 1 minit untuk 10 lokasi stesen pencerap hujan. Analisa graf yang melibatkan proses pemilihan model penukaran kadar hujan terbaik dibuat melalui hasil pengiraan peratusan ralat dan nilai RMS seperti ditunjukkan dalam jadual.

\section{STESEN PADANG BESAR, PERLIS}

Perbandingan graf bagi peratusan masa tahunan $0.01 \%$ hingga $1 \%$ bagi kadar hujan kumulatif untuk tahun 2011 hingga 2013 bagi model-model penukaran dengan data cerapan di Stesen Padang Besar ditunjukkan dalam Rajah 2. Daripada Jadual 2, didapati model Moupfouma memberikan nilai RMS ralat relatif yang terendah dan diikuti dengan model Chebil dan Rahman.

\section{STESEN KOMPLEKS PRAI, PULAU PINANG}

Perbandingan kadar hujan kumulatif model penukaran dengan data cerapan di Stesen Kompleks Prai, Pulau Pinang bagi tahun 2011 hingga 2013 adalah seperti pada Rajah 3. Daripada Jadual 3, didapati model Chebil dan Rahman menunjukkan nilai RMS ralat relatif yang paling rendah dan kemudian diikut oleh model Segal.

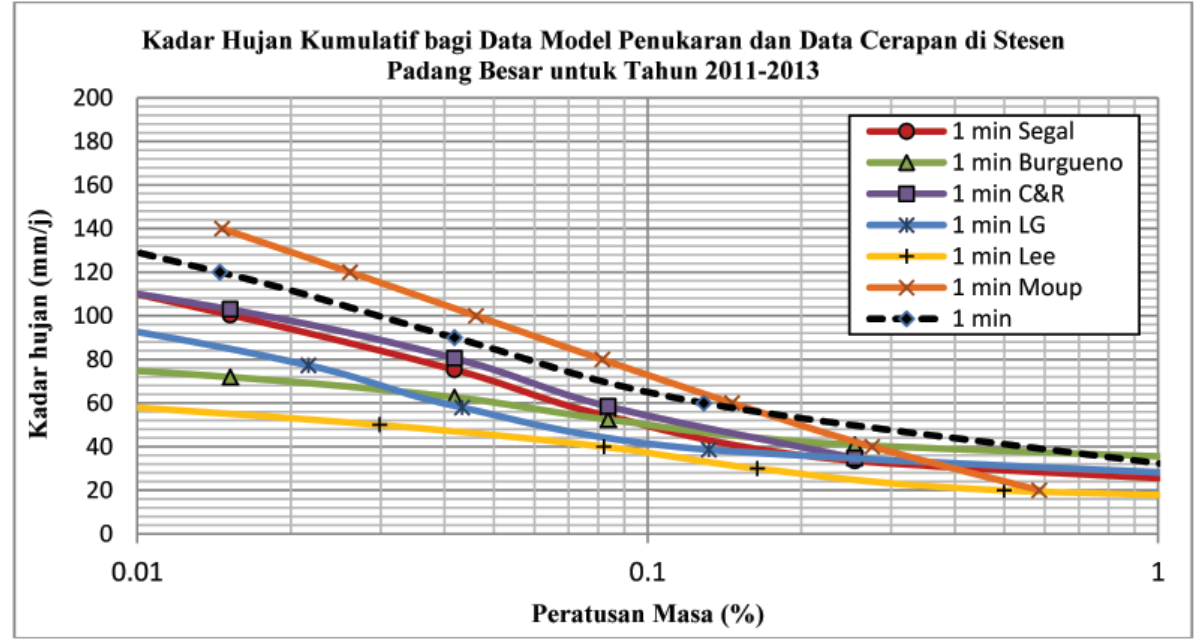

RAJAH 2. Perbandingan kadar hujan kumulatif model penukaran dan data cerapan di Stesen Padang Besar, Perlis bagi tahun 2011 hingga 2013

JADUAL 2. Nilai purata, sisihan piawai dan RMS ralat relatif Model Penukaran Kadar Hujan di Stesen Padang Besar, Perlis bagi tahun 2011 hingga 2013 (kumulatif)

\begin{tabular}{lccc}
\hline Model Penukaran Kadar Hujan & \multicolumn{3}{c}{ Peratusan Ralat Ralatif (\%) } \\
& Purata & Sisihan Piawai & RMS \\
\hline Segal & 24.20 & 7.23 & 25.26 \\
Burgueno & 27.05 & 10.26 & 28.93 \\
C\&R & 16.60 & 5.34 & 17.44 \\
LG & 32.51 & 3.29 & 32.68 \\
Lee & 47.95 & 4.39 & 48.15 \\
Moup & 11.39 & 5.05 & 12.46 \\
\hline
\end{tabular}




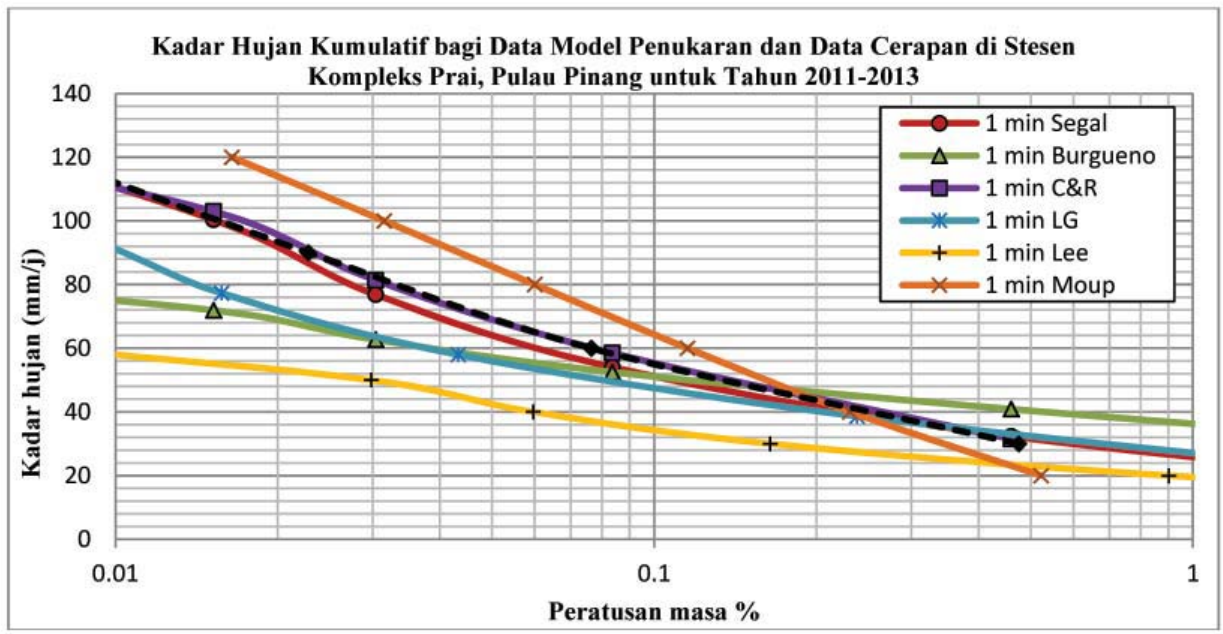

RAJAH 3. Perbandingan kadar hujan kumulatif model penukaran dan data cerapan di Stesen Komples Prai, Pulau Pinang bagi tahun 2011 hingga 2013

JADUAL 3. Nilai purata, sisihan piawai dan RMS ralat relatif Model Penukaran Kadar Hujan di Stesen Komples Prai, Pulau Pinang bagi tahun 2011 hingga 2013 (kumulatif)

\begin{tabular}{lccc}
\hline Model Penukaran Kadar Hujan & \multicolumn{3}{c}{ Peratusan Ralat Ralatif (\%) } \\
& Purata & Sisihan Piawai & RMS \\
\hline Segal & 4.10 & 2.67 & 4.89 \\
Burgueno & 20.34 & 11.43 & 23.33 \\
C\&R & 1.72 & 1.56 & 2.32 \\
LG & 13.57 & 10.21 & 16.98 \\
Lee & 36.73 & 8.47 & 37.69 \\
Moup & 18.92 & 4.02 & 19.35 \\
\hline
\end{tabular}

STESEN POLITEKNIK UNGKU OMAR, PERAK

Rajah 4 menunjukkan perbandingan kadar hujan kumulatif model penukaran dan data cerapan di Stesen Politeknik Ungku Omar, Perak bagi tahun 2011 hingga 2013 untuk julat peratusan masa $0.01 \%$ hingga $1 \%$. Daripada Jadual 4, didapati model Chebil dan Rahman memberikan nilai RMS ralat relatif yang paling rendah dan diikuti dengan model Segal.

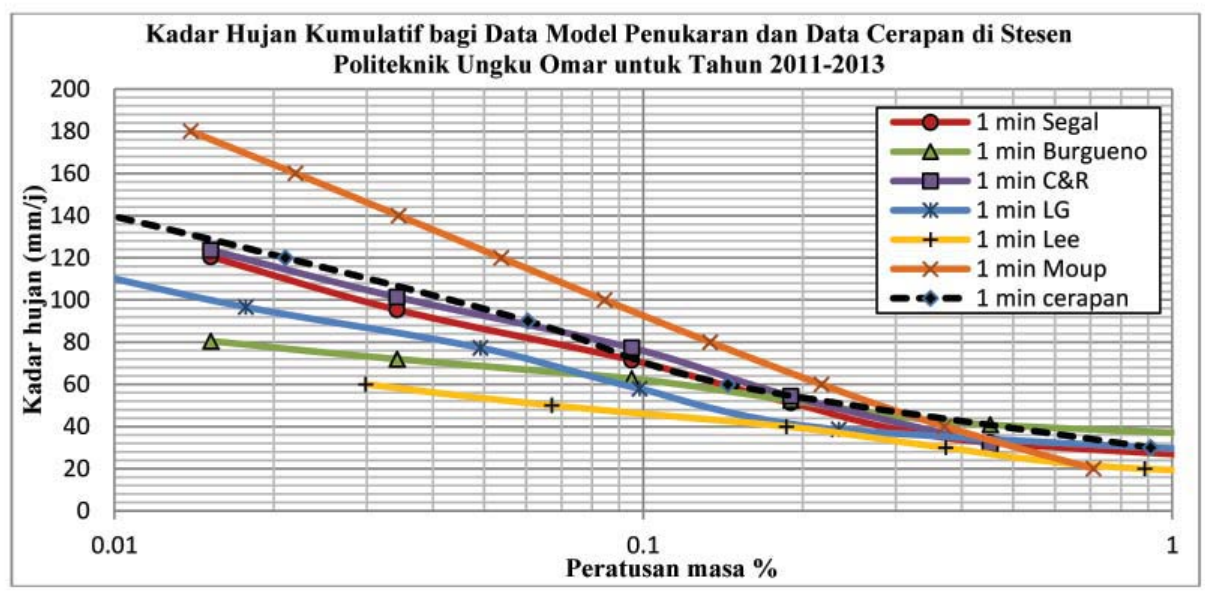

RAJAH 4. Perbandingan kadar hujan kumulatif model penukaran dan data cerapan di Stesen Politeknik Ungku Omar, Perak bagi tahun 2011 hingga 2013 
JADUAL 4. Nilai purata, sisihan piawai dan RMS ralat relatif Model Penukaran Kadar Hujan di Stesen Politeknik Ungku Omar, Perak bagi tahun 2011 hingga 2013 (kumulatif)

\begin{tabular}{lccc}
\hline Model Penukaran Kadar Hujan & \multicolumn{3}{c}{ Peratusan Ralat Ralatif (\%) } \\
& Purata & Sisihan Piawai & RMS \\
\hline Segal & 11.64 & 12.59 & 17.14 \\
Burgueno & 15.84 & 14.02 & 21.15 \\
C\&R & 12.23 & 9.22 & 15.32 \\
LG & 21.24 & 5.80 & 22.01 \\
Lee & 37.63 & 7.23 & 38.32 \\
Moup & 25.83 & 10.57 & 27.91 \\
\hline
\end{tabular}

\section{STESEN WILAYAH PERSEKUTUAN KUALA LUMPUR}

Rajah 5 menunjukkan perbandingan kadar hujan kumulatif model penukaran dan data cerapan di Stesen Wilayah Persekutuan, Kuala Lumpur bagi tahun 2011 hingga 2013 untuk julat peratusan masa $0.01 \%$ hingga $1 \%$. Daripada Jadual 5, didapati model Segal memberikan nilai RMS ralat relatif yang paling rendah dan diikuti dengan model Chebil dan Rahman.

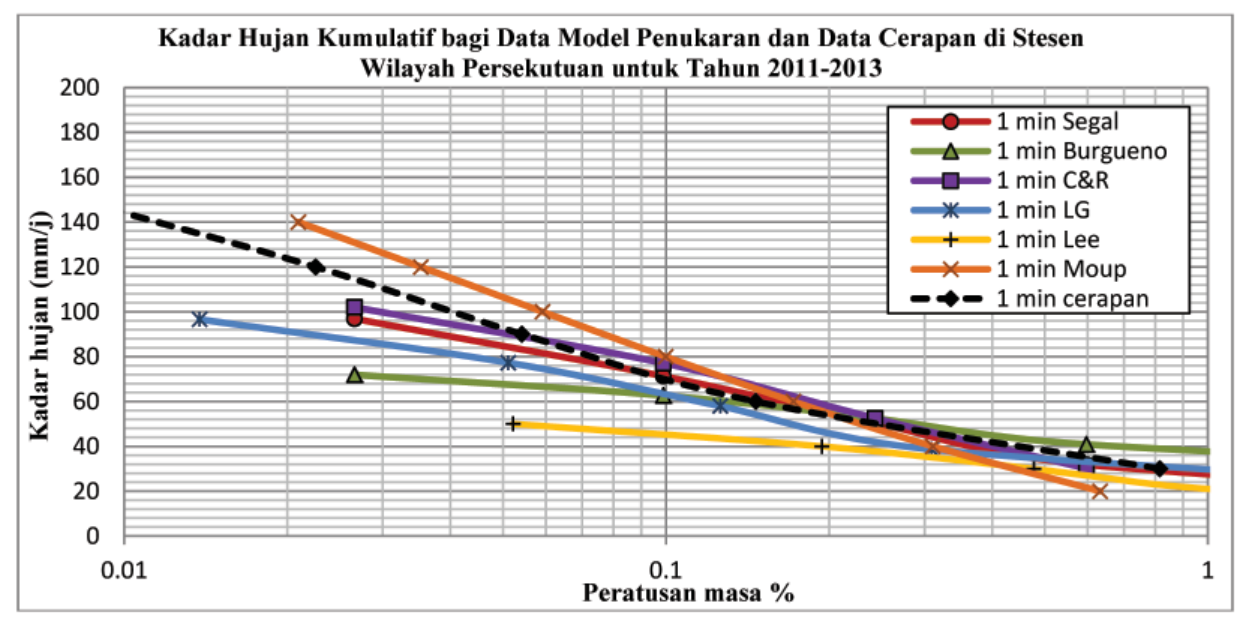

RAJAH 5. Perbandingan kadar hujan kumulatif model penukaran dan data cerapan di Stesen Wilayah Persekutuan bagi tahun 2011 hingga 2013

JADUAL 5. Nilai purata, sisihan piawai dan RMS ralat relatif Model Penukaran Kadar Hujan di Stesen Wilayah Persekutuan bagi tahun 2011 hingga 2013 (kumulatif)

\begin{tabular}{lccc}
\hline Model Penukaran Kadar Hujan & \multicolumn{3}{c}{ Peratusan Ralat Ralatif (\%) } \\
& Purata & Sisihan Piawai & RMS \\
\hline Segal & 6.44 & 4.34 & 7.76 \\
Burgueno & 13.72 & 13.71 & 19.39 \\
C\&R & 6.65 & 5.79 & 8.82 \\
LG & 17.74 & 8.83 & 19.81 \\
Lee & 32.16 & 13.96 & 35.06 \\
Moup & 15.75 & 14.94 & 21.71 \\
\hline
\end{tabular}

\section{STESEN BUKIT FRASER, SELANGOR}

Perbandingan kadar hujan kumulatif model penukaran dan data cerapan di Stesen Bukit Fraser, Selangor bagi tahun 2011 hingga 2013 untuk julat peratusan masa $0.01 \%$ hingga
$1 \%$ adalah seperti pada Rajah 6 . Daripada Jadual 6, didapati model Chebil dan Rahman menunjukkan nilai RMS ralat relatif yang paling rendah. 


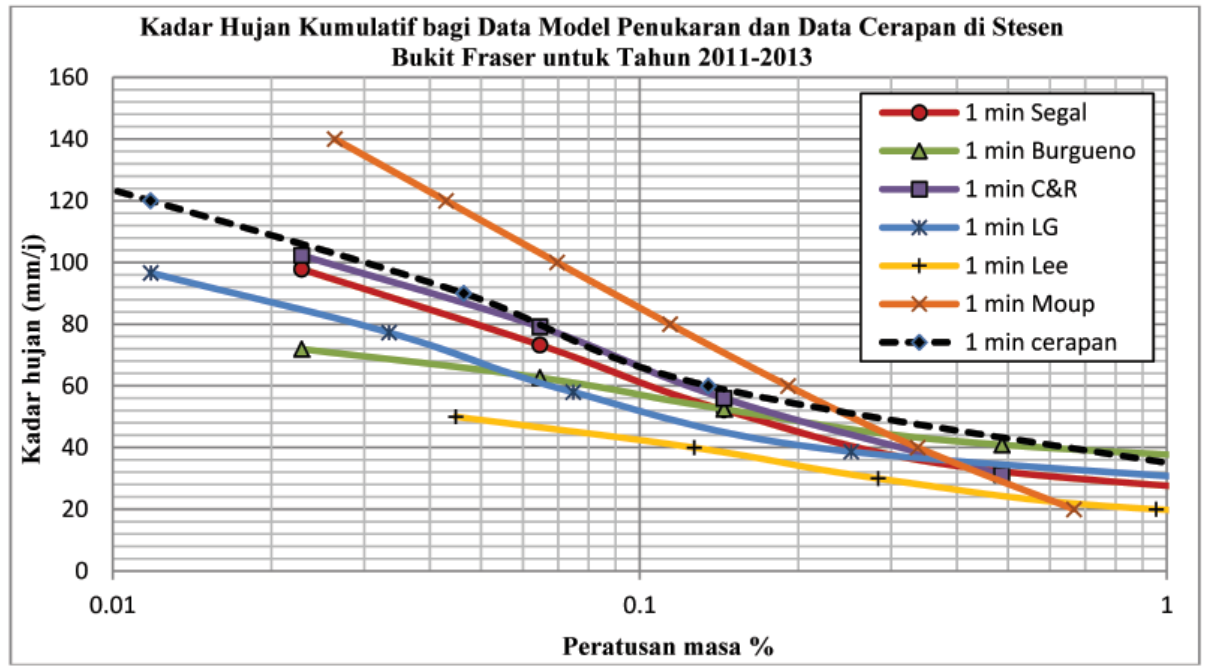

RAJAH 6. Perbandingan kadar hujan kumulatif model penukaran dan data cerapan di Stesen Bukit Fraser, Selangor bagi tahun 2011 hingga 2013

JADUAL 6. Nilai purata, sisihan piawai dan RMS ralat relatif Model Penukaran Kadar Hujan di Stesen Bukit Fraser, Selangor bagi tahun 2011 hingga 2013 (kumulatif)

\begin{tabular}{lccc}
\hline Model Penukaran Kadar Hujan & \multicolumn{3}{c}{ Peratusan Ralat Ralatif (\%) } \\
& Purata & Sisihan Piawai & RMS \\
\hline Segal & 16.50 & 6.73 & 17.82 \\
Burgueno & 16.30 & 9.70 & 18.96 \\
C\&R & 12.79 & 9.41 & 15.87 \\
LG & 22.73 & 2.73 & 22.89 \\
Lee & 34.17 & 12.65 & 36.43 \\
Moup & 19.30 & 10.87 & 22.15 \\
\hline
\end{tabular}

\section{STESEN JPS NEGERI PAHANG}

Rajah 7 menunjukkan perbandingan kadar hujan kumulatif model penukaran dan data cerapan di Stesen JPS Negeri Pahang bagi tahun 2011 hingga 2013 untuk peratusan masa $0.01 \%$ hingga $1 \%$. Daripada Jadual 7 , didapati model Moupfouma memberikan nilai RMS ralat relatif yang paling rendah dan diikuti rapat model Chebil dan Rahman.

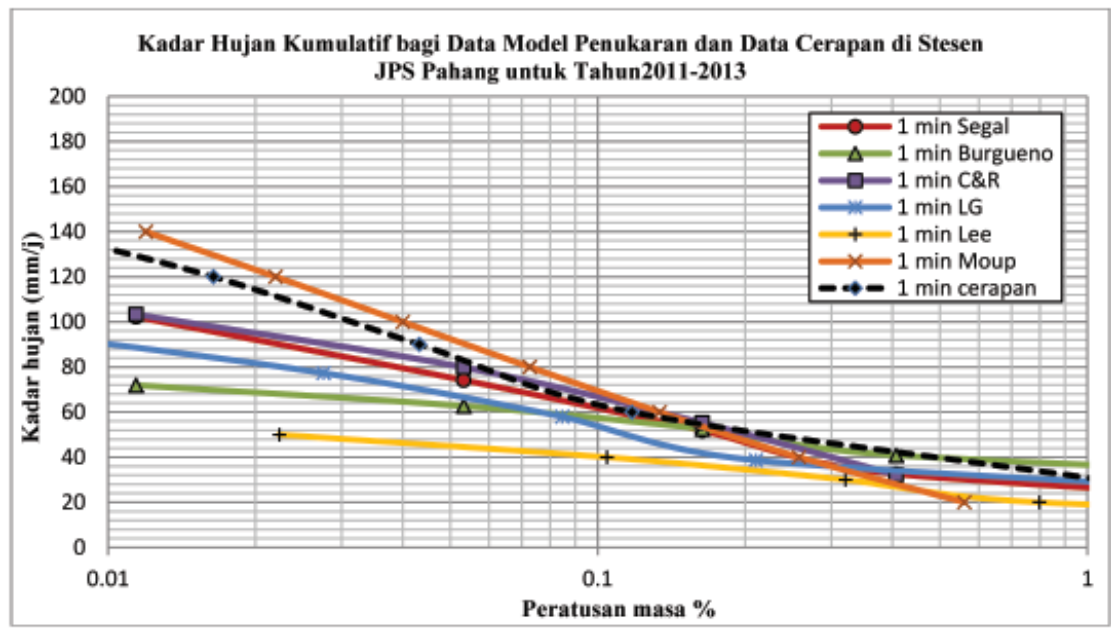

RAJAH 7. Perbandingan kadar hujan kumulatif model penukaran dan data cerapan di Stesen JPS Negeri Pahang bagi tahun 2011 hingga 2013 
JADUAL7. Nilai purata, sisihan piawai dan RMS ralat relatif Model Penukaran Kadar Hujan di Stesen JPS Negeri Pahang bagi tahun 2011 hingga 2013 (kumulatif)

\begin{tabular}{lccc}
\hline Model Penukaran Kadar Hujan & \multicolumn{3}{c}{ Peratusan Ralat Ralatif (\%) } \\
& Purata & Sisihan Piawai & RMS \\
\hline Segal & 14.12 & 10.25 & 17.45 \\
Burgueno & 16.47 & 14.96 & 22.25 \\
C\&R & 12.90 & 4.68 & 13.72 \\
LG & 20.60 & 4.32 & 21.05 \\
Lee & 40.63 & 10.63 & 42.00 \\
Moup & 12.15 & 6.11 & 13.60 \\
\hline
\end{tabular}

\section{STESEN JPS KUALA TERENGGANU, TERENGGANU}

Rajah 8 menunjukkan perbandingan kadar hujan kumulatif model penukaran dan data cerapan di Stesen JPS Kuala Terengganu bagi tahun 2011 hingga 2013 untuk peratusan masa $0.01 \%$ hingga 1\%. Daripada Jadual 8, didapati model Chebil dan Rahman memberikan nilai RMS ralat relatif yang paling rendah.

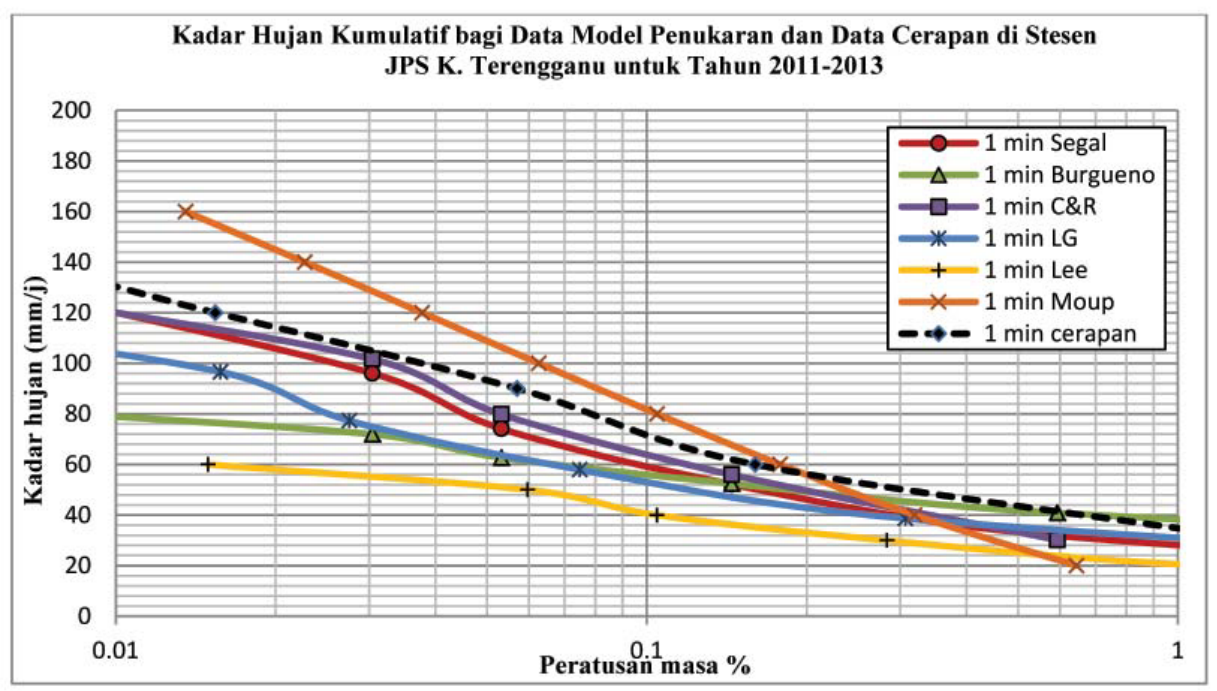

RAJAH 8. Perbandingan kadar hujan kumulatif model penukaran dan data cerapan di Stesen JPS Kuala Terengganu bagi tahun 2011 hingga 2013

JADUAL 8. Nilai purata, sisihan piawai dan RMS ralat relatif Model Penukaran Kadar Hujan di Stesen JPS Kuala Terengganu bagi tahun 2011 hingga 2013 (kumulatif)

\begin{tabular}{lccc}
\hline Model Penukaran Kadar Hujan & \multicolumn{3}{c}{ Peratusan Ralat Ralatif (\%) } \\
& Purata & Sisihan Piawai & RMS \\
\hline Segal & 16.52 & 8.55 & 18.60 \\
Burgueno & 20.33 & 14.92 & 25.22 \\
C\&R & 13.50 & 10.51 & 17.11 \\
LG & 22.63 & 3.27 & 22.87 \\
Lee & 44.83 & 2.96 & 44.93 \\
Moup & 27.04 & 11.68 & 29.45 \\
\hline
\end{tabular}

\section{STESEN JPS KOTA BHARU, KELANTAN}

Perbandingan kadar hujan kumulatif model penukaran dan data cerapan di Stesen JPS Kota Bharu bagi tahun 2011 hingga
2013 untuk peratusan masa $0.01 \%$ hingga $1 \%$ adalah seperti pada Rajah 9. Daripada Jadual 9, didapati model Chebil dan Rahman memberikan nilai RMS ralat relatif yang paling rendah dan diikuti oleh model Segal. 


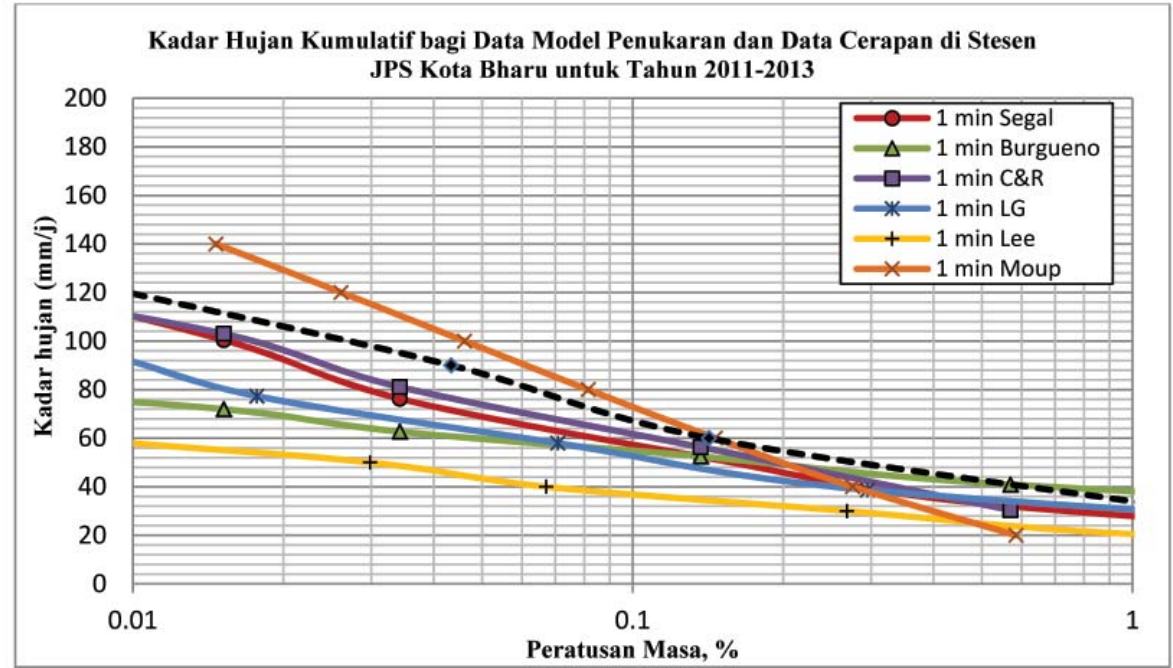

RAJAH 9. Perbandingan kadar hujan kumulatif model penukaran dan data cerapan di Stesen JPS Kota Bharu bagi tahun 2011 hingga 2013

JADUAL 9. Nilai purata, sisihan piawai dan RMS ralat relatif Model Penukaran Kadar Hujan di Stesen JPS Kota Bharu bagi tahun 2011 hingga 2013 (kumulatif)

\begin{tabular}{lccc}
\hline Model Penukaran Kadar Hujan & \multicolumn{3}{c}{ Peratusan Ralat Ralatif (\%) } \\
& Purata & Sisihan Piawai & RMS \\
\hline Segal & 16.49 & 3.85 & 16.93 \\
Burgueno & 17.99 & 16.67 & 24.53 \\
C\&R & 12.02 & 8.19 & 14.54 \\
LG & 21.55 & 7.34 & 22.76 \\
Lee & 44.22 & 5.47 & 44.55 \\
Moup & 26.18 & 13.76 & 29.58 \\
\hline
\end{tabular}

STESEN KUCHING, SARAWAK

Perbandingan kadar hujan kumulatif model penukaran dan data cerapan di Stesen Kuching, Sarawak bagi tahun 2011 hingga 2013 untuk peratusan masa $0.01 \%$ hingga $1 \%$ adalah seperti pada Rajah 10. Daripada Jadual 10, didapati model Segal memberikan nilai RMS ralat relatif yang paling rendah dan diikuti rapat model Chebil dan Rahman.

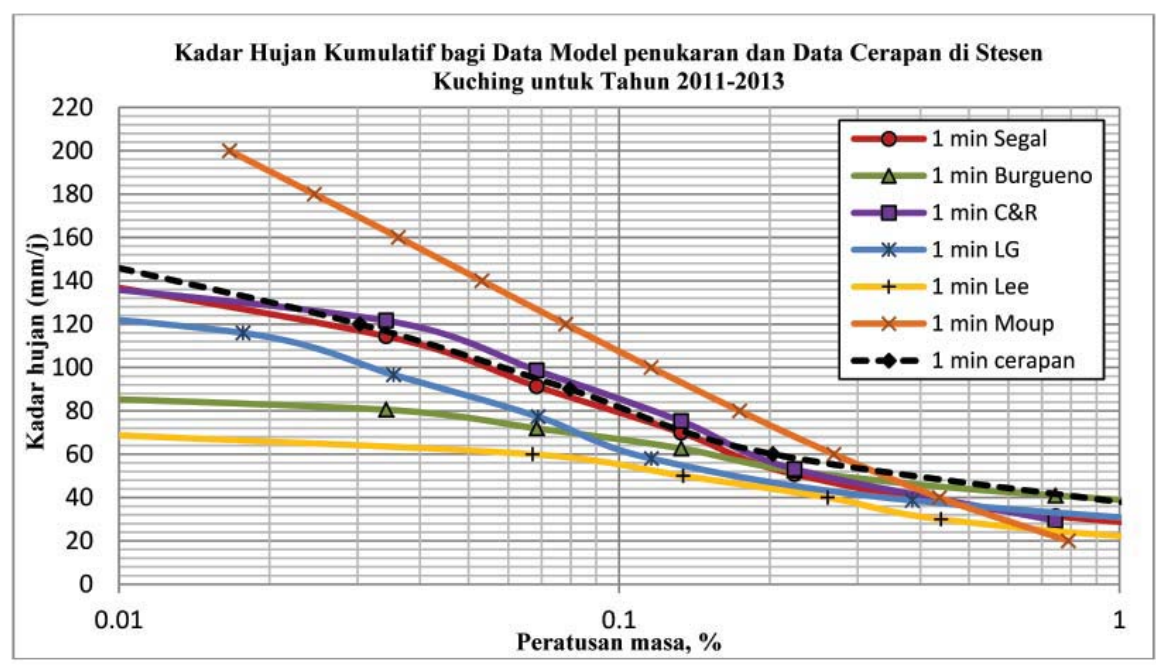

RAJAH 10. Perbandingan kadar hujan kumulatif model penukaran dan data cerapan di Stesen Kuching bagi tahun 2011 hingga 2013 
JADUAL 10. Nilai purata, sisihan piawai dan RMS ralat relatif Model Penukaran Kadar Hujan di Stesen Kuching bagi tahun 2011 hingga 2013 (kumulatif)

\begin{tabular}{lccc}
\hline Model Penukaran Kadar Hujan & \multicolumn{3}{c}{ Peratusan Ralat Ralatif (\%) } \\
& Purata & Sisihan Piawai & RMS \\
\hline Segal & 11.23 & 13.41 & 17.49 \\
Burgueno & 20.53 & 15.11 & 25.50 \\
C\&R & 11.18 & 13.68 & 17.66 \\
LG & 19.20 & 6.07 & 20.14 \\
Lee & 40.85 & 8.38 & 41.70 \\
Moup & 35.81 & 9.11 & 36.95 \\
\hline
\end{tabular}

\section{STESEN KIANSAM, SABAH}

Perbandingan kadar hujan kumulatif model penukaran dan data cerapan di Stesen Kiansam, Sabah bagi tahun 2011 hingga 2013 untuk peratusan masa $0.01 \%$ hingga 1\% adalah seperti pada Rajah 11. Daripada Jadual 11, didapati model Chebil dan Rahman memberikan nilai RMS ralat relatif yang paling rendah dan diikuti model Segal.

\section{RUMUSAN MODEL PENUKARAN KADAR HUJAN YANG TERBAIK DI MALAYSIA}

Model penukaran kadar hujan yang memberikan ralat yang besar, akan turut menyumbang ralat dalam pengiraan pelemahan hujan yang seterusnya boleh menjejaskan kebolehsediaan dan kebolehcapaian sesebuah sistem perhubungan satelit. Justeru, pemilihan model penukaran kadar hujan yang terbaik adalah sangat penting dalam menentukan pelemahan hujan bagi merekabentuk sebuah sistem perhubungan satelit yang mempunyai kebolehsediaan dan kebolehcapaian yang tinggi.

Jadual 12 menunjukkan rumusan hasil keputusan model penukaran kadar hujan yang terbaik di 10 lokasi di Seluruh Malaysia. Di kalangan model-model empirik yang digunakan di dalam kajian ini, didapati model Chebil dan Rahman memberikan keputusan terbaik dalam perbandingan modelmodel penukaran kadar hujan berdasarkan nilai RMS yang terendah berbanding model-model lain.

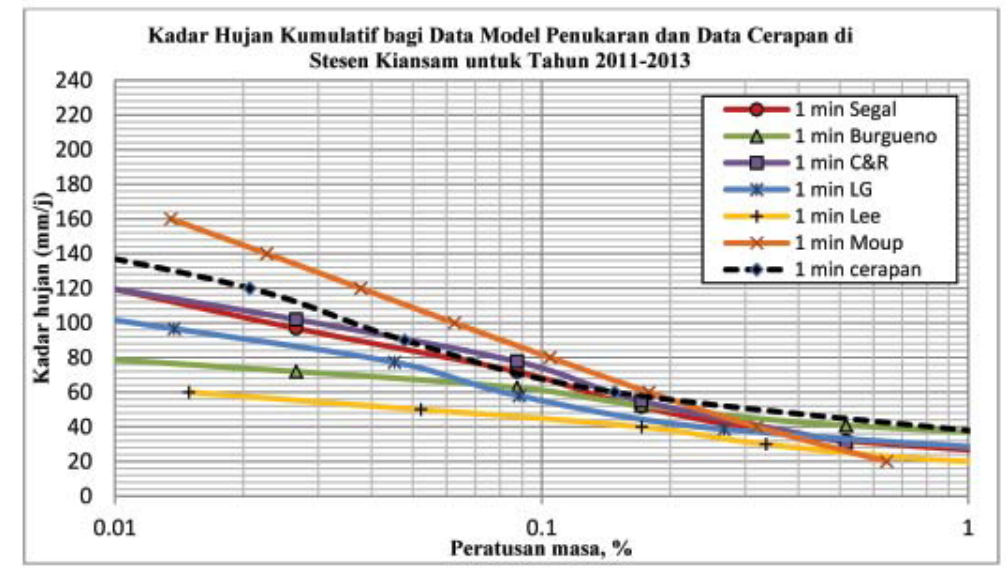

RAJAH 11. Perbandingan kadar hujan kumulatif model penukaran dan data cerapan di Stesen Kiansam bagi tahun 2011 hingga 2013

JADUAL 11. Nilai purata, sisihan piawai dan RMS ralat relatif Model Penukaran Kadar Hujan di Stesen Kiansam bagi tahun 2011 hingga 2013 (kumulatif)

\begin{tabular}{lccc}
\hline Model Penukaran Kadar Hujan & \multicolumn{3}{c}{ Peratusan Ralat Ralatif (\%) } \\
& Purata & Sisihan Piawai & RMS \\
\hline Segal & 11.66 & 10.67 & 15.80 \\
Burgueno & 17.43 & 19.67 & 26.28 \\
C\&R & 12.44 & 3.33 & 12.88 \\
LG & 21.61 & 2.90 & 21.81 \\
Lee & 44.90 & 8.91 & 45.77 \\
Moup & 22.22 & 3.29 & 22.46 \\
\hline
\end{tabular}


JADUAL 12. Ringkasan hasil keputusan perbandingan model penukaran kadar hujan dan data cerapan bagi 10 lokasi di seluruh Malaysia

\begin{tabular}{lc}
\hline Nama Stesen & $\begin{array}{c}\text { Model Penukaran Kadar } \\
\text { Hujan Terbaik }\end{array}$ \\
\hline PERLIS (Stesen Padang Besar di Titi Keretapi) & Model Moupfouma \\
PRAI, PENANG (Stesen Kompleks Prai) & Model Chebil \& Rahman \\
PERAK (Stesen Politeknik Ungku Omar) & Model Chebil \& Rahman \\
KUALA LUMPUR (Stesen JPS Wilayah Persekutuan) & Model Segal \\
SELANGOR (Stesen Bukit Fraser) & Model Chebil \& Rahman \\
PAHANG (Stesen JPS Negeri Pahang, Kuantan) & Model Moupfouma \\
TERENGGANU (Setor JPS Kuala Terengganu) & Model Chebil \& Rahman \\
KELANTAN (Setor JPS Kota Bharu) & Model Chebil \& Rahman \\
SARAWAK (Stesen Kuching Airport) & Model Segal \\
SABAH (Stesen Kiansam) & Model Chebil \& Rahman \\
\hline
\end{tabular}

Model Chebil dan Rahman disyorkan untuk digunakan di 6 stesen di Malaysia, di antaranya Stesen Kompleks Prai, Pulau Pinang, Stesen Politeknik Ungku Omar, Perak, Stesen Bukit Fraser, Selangor, Stesen Setor JPS Kuala Terengganu, Terengganu, Stesen Setor JPS Kota Bharu, Kelantan dan Stesen Kiansam. Model ini dibangunkan berdasarkan pengubahsuaian model Segal menggunakan data kadar hujan di Malaysia dan Singapura untuk disesuaikan dengan ciri-ciri di kawasan tropika dan pekali regresi model ini diperolehi daripada aktiviti ribut petir di mana hujan jenis stratiform (Chebil \& Rahman 1999). Oleh kerana model Chebil dan Rahman dibangunkan berdasarkan model Segal, daripada kesemua hasil keputusan dapat diperhatikan trend model Segal dan model Chebil dan Rahman adalah hampir sama. Model Segal dibangunkan dengan mengambil kira beberapa faktor penting seperti integrasi masa yang berbeza untuk tolok hujan dan peratusan masa pada kadar hujan yang tertentu berlaku, yang memberi kesan kepada taburan hujan (Segal 1986). Model ini adalah disyorkan untuk digunakan di 2 stesen di Malaysia iaitu Stesen JPS Wilayah Persekutuan, Kuala Lumpur dan Stesen Kuching Airport, Sarawak.

Model Moupfouma pula adalah model yang disyorkan di 2 stesen di Malaysia iaitu Stesen Padang Besar di Titi Keretapi, Perlis dan Stesen JPS Negeri Pahang, Kuantan, Pahang. Ketepatan model Moupfouma bergantung kepada data hujan yang digunakan untuk membangunkan model ini, terutamanya bagi kawasan yang mempunyai keamatan hujan yang rendah (Moupfouma \& Martin 1995). Menurut kajian Mazlina (2013), model Moupfouma dan Martin (1995) adalah antara model kadar hujan yang dicadangkan sesuai digunakan di Malaysia berdasarkan kepada kajian sebelum ini yang memberi keputusan terbaik untuk taburan hujan dengan kadar 1 minit di Singapura, Brazil, Indonesia, Malaysia dan Negara tropika yang lain.

Daripada keseluruhan hasil keputusan, dapat diperhatikan trend model Burgueno yang memberikan bacaan ralat relatif yang rendah pada peratusan masa $0.1 \%$ hingga $1 \%$, namun model ini memberikan bacaan ralat relatif yang besar untuk peratusan masa $0.01 \%$ hingga $0.1 \%$. Menurut kajian Chun dan Mandeep, model Burgueno tidak sesuai digunakan untuk penukaran kadar hujan bagi integrasi masa 30 minit dan 60 minit kerana memberikan peratusan ralat yang besar (Chun \& Mandeep 2013). Ini adalah kerana model Burgueno mengambil kira kadar titisan hujan dan jumlah relatif antara hujan stratiform dan hujan perolakan. Bagi model Lavergnat dan Golé, nilai-nilai RMS yang diperolehi adalah di antara $20 \%$ hingga $40 \%$ bagi kesemua hasil keputusan. Pekali $\alpha$ yang dicadangkan dalam model Lavergnat dan Golé menghadkan ketepatan ramalan model ini. Nilai pekali $\alpha$ perlu dikira untuk kawasan-kawasan iklim yang lain bagi meningkatkan ketepatan model ini.

Model Lee merupakan model penukaran kadar hujan yang memberikan nilai RMS ralat penukaran yang terlalu besar dan tidak digalakkan untuk digunakan di Malaysia. Ini adalah kerana model dibangunkan menggunakan sela masa pengukuran yang pendek yang memberikan statistik yang ekstrem. Model ini juga dibangunkan daripada kejadian hujan stratiform yang dipercayai kurang praktikal di Malaysia yang mempunyai kadar hujan yang tinggi (Lee et al. 2000).

Secara keseluruhan, didapati model Chebil dan Rahman merupakan Model Penukaran Kadar Hujan untuk sela masa 60 minit kepada 1 minit yang paling sesuai untuk diguna pakai di Malaysia. Walaupun di beberapa stesen pencerap hujan menunjukkan model Segal dan model Moupfouma sebagai model penukaran yang terbaik, namun daripada keputusan nilai RMS ralat relatif di stesen-stesen tersebut, dapat diperhatikan model Chebil dan Rahman memberikan keputusan kedua yang terbaik dengan nilai RMS ralat yang rendah. Oleh itu, berdasarkan kajian ini, Model Penukaran Kadar Hujan untuk sela masa 60 minit kepada 1 minit yang disyorkan untuk diguna pakai di Malaysia adalah model Chebil dan Rahman.

\section{KESIMPULAN}

Berdasarkan hasil keputusan yang diperolehi dalam kajian ini menunjukkan model Chebil dan Rahman merupakan model penukaran kadar hujan yang paling sesuai diguna pakai di kebanyakan stesen pencerap hujan di Malaysia berdasarkan 
kepada nilai RMS ralat relatif paling minimum yang diberikan model tersebut apabila perbandingan antara model-model penukaran kadar hujan yang lain. Manakala model Lee pula adalah model terlebih anggaran yang menyumbang peratusan nilai RMS ralat relatif maksimum pada semua stesen pencerap hujan dalam kajian ini.

\section{RUJUKAN}

Burgueno, A.; Puigcerver, M.; Vilar, E. 1988. Influence of rain gauge integration time on the rain rate statistics used in microwave communications. Ann Telecommun 43: 522-527.

Chebil, J. \& Rahman, T. A. 1999. Rain rate statistical conversion for the prediction of rain attenuation in Malaysia. Electronics Letters 35(12): 1019-1021.

Chun, O. W. \& Mandeep, J. S. 2013. Empirical methods for converting rainfall rate distribution from several higher integration times into a 1-minute integration time in Malaysia. Goefizika 30: 143-154.

Hadi, M.B.H. 2011. Mengkaji bukti perubahan iklim di projek pengairan Barat Laut Selangor. Kertas Projek Ijazah Sarjana, Universiti Teknologi Malaysia.

Hasniza, H. 2013. Kajian Pelemahan Perambatan Isyarat Komunikasi Satelit oleh Hujan Pada Jalur Ku dan Ka di Malaysia. Tesis Iajazah Sarjana, Universiti Kebangsaan Malaysia.

ITU-R Recommendation ITU-R P.837-6. 2012. Characteristics of precipitation for propagation modelling. Geneva: International Telecommunication Union (ITU).

ITU 2003a, Characteristics of precipitation for propagation modeling. Radiocommunication Sector Recommendation ITU-R P.837-4, International Union of Telecommunications, $8 \mathrm{pp}$.

ITU 2003b, Propagation data and prediction methods required for the design of Earth-space telecommunication systems. Radiocommunication Sector Recommendation ITU-R P.618-8, International Union of Telecommunications, $7 \mathrm{pp}$.

Nor Irza Shakhira Bakhtir* \& Mandeep Singh Jit Singh

Jabatan Kejuruteraan Elektrik, Elektronik dan Sistem

Fakulti Kejuruteraan dan Alam Bina

Universiti Kebangsaan Malaysia (UKM)

43600 UKM Bangi, Malaysia

Telefon: +6012-6523029

*Penulis koresponden; emel: irza_shakhira2002@yahoo. com

Tarikh serahan: 30 Januari 2015

Tarikh terima: 14 April 2015
ITU 2006, Conversion of 1-minute rain rate statistics from various integration time data. Radiocommunication Sector Recommendation WP3J, PDNR ITU-R P.[CONV_RAIN RATE], International Union of Telecommunications, $\overline{5}$ pp.

Kamal, S.A.R., Tharek, A.R. \& Din, J. 2008. Rain contour map in Malaysia for microwave communication. Contemporary Studies on Rain Attenuation in Malaysia: 80-89.

Lavergnat, J. \& Gole, P. 1998. A Stochastic Raindrop Time Distribution Model. Journal of Applied Meteorology 37: 805-818.

Lee, J., Kim, Y. \& Kim, J. 2000. Empirical Conversion Process Of Rain Rate Distribution For Various Integration Time. Korean Inst. Electromagnet Eng. Sci. 2: 2-6.

Mandeep, J. S. \& Hassan, S. I. S. 2008. 60- to 1-Min RainfallRate conversion: Comparison of existing prediction methods with data obtained in the Southeast Asia Region. Journal of Applied Meteorology and Climatology 47(3): 925-930. doi:10.1175/2007JAMC1600.1

Mandeep, J. S., Idris, S. S. H. \& Mohd, F. A. 2007. Rainfall attenuation and rainfall rate measurements in Malaysia comparison with prediction models. American Journal of Applied Science 4(1): 5-7.

Mazlina, M.Y. 2013. Kajian taburan hujan di malaysia dengan menggunakan ramalan perbandingan model. Tesis Iajazah Sarjana, Universiti Kebangsaan Malaysia

Moupfouma, F. \& Martin, L. 1995. Modelling Of The Rainfall Rate Cumulative Distribution For The Design Of Satellite And Terrestrial Communication Systems. International Journal of Satellite Communications 13(October 1994): 105-115.

Segal, B. 1986. The Influence of Raingage Integration Time on Measured Rainfall-Intensity Distribution Functions. Journal of Atmospheric and Oceanic Technology 3: 662-671.

Sharifah, S.S.J. 2010. Analisa amaun hujan di Semenanjung Malaysia. Tesis Ph.D., Universiti Kebangsaan Malaysia. 